\title{
An integrated approach to identification and conservation of medicinal plants in the tropical forest - a Brazilian experience
}

\author{
Luiz Claudio Di Stasi* \\ Laboratory of Phytomedicines (LaFit-Botu), Department of Pharmacology, Instituto de \\ Biociências, Unesp, Botucatu, 18618-000, SP, Brazil
}

Received 7 March 2005; Accepted 6 June 2005

\begin{abstract}
An integrated and interdisciplinary research programme with native medicinal plants from tropical forests has been performed in order to obtain new forest products for sustainable use in regional markets vis-à-vis ecosystem conservation. For the success of this programme ethnopharmacological studies are very important with respect to (i) identification of useful plants including medicinal and aromatic species; (ii) recuperation and preservation of traditional knowledge about native plants; and (iii) identification of potential plants with economic value. The plants are selected with a view to evaluate efficacy and safety (pharmacological and toxicological studies), and phytochemical profile and quality control (phytochemical and chromatographic characterization). These studies are very important to add value to plant products and also to mitigate unscrupulous exploitation of medicinal plants by local communities, since multiple use of plants represents an excellent strategy for sustaining the tropical ecosystem through ex situ and in situ conservation. Thus, conservation of tropical resources is possible in conjunction with improvements in the quality of life of the traditional communities and production of new products with therapeutic, cosmetic and 'cosmeceutic' value.
\end{abstract}

Keywords: ethnopharmacology; ex situ conservation; in situ conservation; medicinal plants; sustainable management; tropical forest

\section{Introduction}

In Brazil, like many other developing countries, a high tropical biodiversity is related to the presence of several human groups that live in tropical forests. These traditional or rural communities have a rich knowledge of the medicinal value of tropical plants, but do not have access to pharmaceuticals. Thus, in order to provide increased access to pharmaceuticals for the local communities, it is very important that the industrial base to produce modern medicines is developed locally at a competitive cost commensurate with market price.

According to World Health Organization (WHO), 80\% of the population, especially in developing countries,

\footnotetext{
*Corresponding author. E-mail: Idistasi@ibb.unesp.br
}

depend on medicinal plants for their primary health care (Farnsworth and Morris, 1976). Several pharmaceutical industries and research institutions have mainly two goals in using plants as sources of therapeutic agents: (i) to isolate bioactive compounds for direct use as drugs, e.g. morphine and digoxin; and (ii) to produce bioactive compounds from novel or known structures as lead compounds for semi-synthesis to produce patentable entities of higher activity and/or lower toxicity, e.g. taxotere and verapamil.

However, use of the whole plant or plant part(s) as a herbal remedy is an important approach in providing new therapeutic products. The development of standardized phytomedicine products with proven efficacy, safety and quality is an important strategy in providing access to new medicinal products, because herbal medicines usually cost less than synthetic drugs, standardization 
and quality control are feasible, and the occurrence of undesirable side-effects seems to be less frequent when compared to synthetic drugs. Standardization of phytomedicines could be best realized by considering three essential aspects: (i) selection of the plant species for use and studies of new phytomedicines is based on traditional knowledge and consequent benefit sharing; (ii) pharmacological, toxicological and phytochemical evaluation of the selected medicinal plants is appropriately done to ascertain their efficacy, safety and quality control; and (iii) strategic utilization of the biological material for the sustainable use of multiple forest resources and conservation of ecosystems.

The present paper highlights meaningful considerations arising from the integrated medicinal plants research performed in Brazil that may be useful to other countries with tropical forest vegetation and traditional communities. The integrated approach to medicinal plant research (Fig. 1) includes a sequence for the study of popular medicinal plants used in several Brazilian regions with a view to providing better access to medicines, standardization of phytomedicines and improvement of the life quality of the forest people vis-à-vis environmental conservation. Our experiences in the Brazilian Amazon and Tropical Atlantic Rain Forests (Mata Atlântica) underpin three main priority aspects: (i) accomplishment of an ethnopharmacological survey in order to support laboratory studies (pharmacological, toxicological and phytochemical) to determine potential forest species with economic value and to promote preservation of the traditional knowledge; (ii) sustainable (ex situ and in situ conservation) raw material production of the medicinal plants for quality control to realize rational exploitation with environmental conservation; and (iii) standardization of phytomedicines for production of herbal remedies with efficacy, safety and

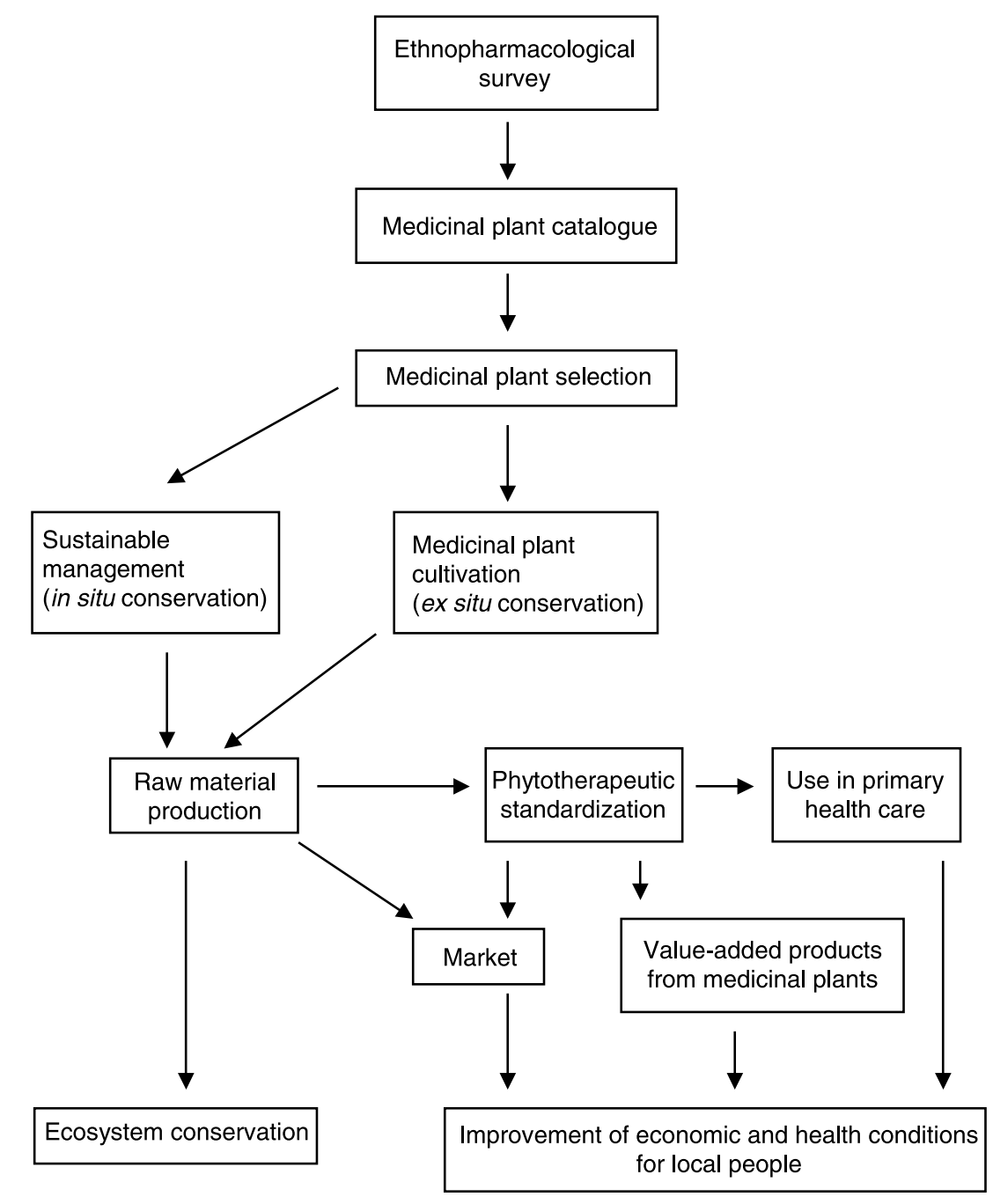

Fig. 1. Flow chart of sequence for the integrated approach research into medicinal plants. 
quality control for use both in primary health care and as commercial products.

\section{Ethnopharmacology}

\section{Ethnopharmacology—an old concept revisited}

The popular knowledge about the medicinal value of plant species has been the main goal of several disciplines such as ethnobotany, ethnomedicine, folk medicine and ethnopharmacology. Despite the concept of ethnopharmacology as a highly diversified approach to drug discovery involving the observation, description and experimental investigation of indigenous drugs and their biological activities (Bruhn and Holmstedt, 1980), and ethnobotany as the study of knowledge and concepts developed by human groups about the plant world (Posey, 1986; Prance, 1991), our research team uses the term 'ethnopharmacology' as the identification and registration of the different medicinal uses of plant species by different human groups. This definition is, in fact, an adaptation of an old concept of ethnopharmacology (Casamada, 1968), and is based on two practical aspects: (i) ethnobotany is not only based on the survey of medicinal uses of plant species in different human groups, and (ii) pharmacology is usually referred to as the studies performed to determine pharmacological and toxicological effects of medicinal plants.

\section{Ethnopharmacology as the main method of medicinal plant selection}

Several approaches for selecting plants for investigation have been used. The most common strategies are randomized selection followed by chemical or pharmacological screening; selection based on chemical composition, i.e. chemotaxonomical approach; and selection based on traditional usage, i.e. ethnopharmacology. However, a combination of ethnopharmacological and chemotaxonomic data may be more useful.

The value of plants used in traditional medicine for drug discovery is uncontestable (Young, 1999; Fabricant and Farnsworth, 2001; Rates, 2001). According to Farnsworth et al. (1989), 88\% of the 119 natural compounds used in modern medicine have the same or related use described in traditional medicine. Further, it was discovered that these compounds were derived from only 94 species of plants. Considering that the number of higher plant species is estimated at approximately 250,000 (Cronquist, 1988; Fabricant and Farnsworth, 2001), there is a great number of plants that remain to be studied as a source of new drugs or phytomedicines. It is estimated that only about
$6 \%$ of these plants have been screened for biological activity, and 15\% have been evaluated phytochemically (Verpoorte, 2000).

If traditional medicine is the main approach to selection of medicinal plants, it is important to note that knowledge heritage on medicinal plants is a dynamic concern in human groups (Savastano and Di Stasi, 1996). Because of this it is very important to perform new surveys for registration of the popular and traditional uses of tropical forest species. In fact, the sum total of human knowledge about the types, distribution, ecology, methods of management and methods of extracting the useful properties of medicinal plants is rapidly declining-a continuation of a process of loss of local cultural diversity that has been under way for hundreds of years (Hamilton, 2003). Unlike many tropical countries, where the use of medicinal plants is well defined and distinctly organized in the traditional medicine systems, e.g. Ayurveda, Unani and Traditional Chinese Medicine, in Brazil studies on medicinal plants are insufficient to support interdisciplinary research (Brito and Brito, 1993). Therefore, new ethnopharmacological studies are necessary to provide recuperation and conservation of the knowledge about native medicinal plants and to permit an adequate selection of medicinal plants for pharmacological, toxicological and phytochemical studies.

In Brazil, there are five important ecological regions, Brazilian Amazon Forest, Tropical Atlantic Forest, Pantanal, Cerrado and Caatinga, all of which have a rich biodiversity and a great number of endemic medicinal plants. Several ethnopharmacological and ethnobotanical studies have been carried out in Brazil, particularly in the Brazilian Amazon (see review by Brito and Brito, 1993), but new studies are necessary for data accreditation/ actualization. Since 1989, our research group has been involved in ethnopharmacological studies in the Brazilian Amazon (Di Stasi et al., 1994) and Tropical Atlantic Forests (Di Stasi et al., 2002). Several medicinal plants have since been selected for pharmacological, toxicological and phytochemical studies with a view to phytomedicine standardization. Criteria adopted by our research group to select medicinal plants for further investigation were based on: (i) availability of plant material for extraction keeping in view the possibilities for cultivation or sustainable management; (ii) economic value of medicinal plants in local or international markets; and (iii) availability of pharmacological methods adequate for evaluation of the traditional uses.

\section{Sustainable raw material production}

Since the demand for raw material from medicinal plants has increased, both in developing and developed 
countries, due to the recognition that herbal remedies are effective and safe to use, and with the international market of medicinal plant products over US $\$ 19.4$ billion per year (Laird and Pierce, 2002), the production of raw material from medicinal plants is a very important aspect for sustainable development of phytomedicines and new drugs. In fact, a wide range of products could be obtained from medicinal plants (Fig. 2). Considering that multiple use of forest resources is better for environmental conditions, raw material from medicinal plants could be used as the source of several forest products, e.g. herbal teas, standardized phytomedicines, new drugs, pharmaceutical auxiliary products, cosmetics, 'cosmeceutics' and nutraceutical dietary products.

Rational use of these forest resources improves the economy and health conditions of forest people, while providing development of a local pharmaceutical and phytomedicine industry. Since medicinal plants are potentially renewable natural resources, their conservation and sustainable use involves an integrated scientific approach, particularly in respect to production of raw material by natural and sustainable exploitation or conventional cultivation. The production of raw material from medicinal plants can be accomplished by ex situ and in situ conservation. These two essential approaches are very important to promote the sustainable use of forest resources. Many medicinal plants in their natural habitat are scattered so it is difficult to economically collect and process them.

Ex situ conservation is defined as plant conservation outside natural habitats by cultivating and maintaining medicinal plants in botanic gardens or other suitable sites, and through long-term preservation of plant propagules in gene banks, plant tissue culture and standardized extracts for further chemical and pharmacological studies. The cultivation of medicinal plants includes several studies for domestication of plant species, including propagation, adaptation to cultivation, and other biological characteristics such as growth and development, seed dispersion, pollination and senescence. On the other hand, several problems need to be addressed in order to obtain a good economic yield of plant products. Some of these problems are related to agro-climate and ecological conditions, soil, incidence of pests and diseases, use of adequate propagation methods for each plant species and proper conditions for processing raw materials.

If the best way to provide raw material is to cultivate the plants, it is important to note that cultivation is

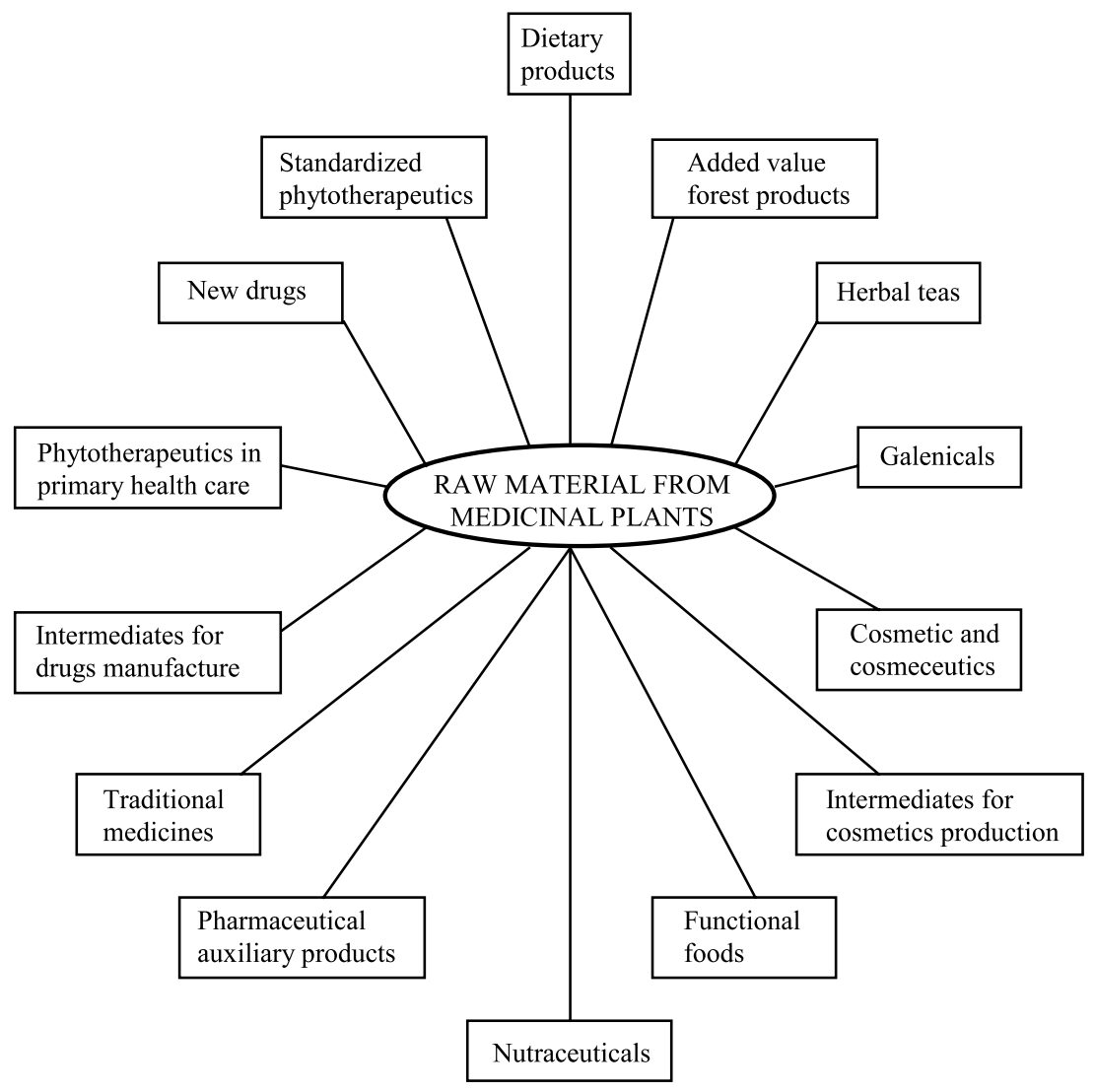

Fig. 2. Main uses of raw materials from medicinal plants. 
possible for some medicinal plants, particularly those that grow under direct sunlight conditions as occurs in disturbed areas of tropical forest or those plants from secondary vegetation. On the other hand, medicinal plants that live just in primary forests need special conditions to grow and develop since their cultivation will be very difficult. For such medicinal plants, the sustainable management in natural areas is more appropriate in order to permit their exploitation with ecosystem conservation.

It is desirable that wherever possible it is always better to have cultivation of medicinal plants rather than to collect them from forest sites, since cultivation is the way to provide raw material without further endangering the survival of those species. Other advantages of organized cultivation of medicinal plants is to ensure availability of raw material of uniform quality and consistent chemical composition by exercising control on genetic fidelity of the plant material, climate/soil conditions of growing areas, agrotechnological cultural practices, optimum harvesting etc.

On the other hand, in situ conservation of medicinal plants provides a sustainable use and extraction of medicinal plants from tropical forests and represents an important approach to ecosystem conservation. It has been well established that the best and most costeffective way of protecting biological and genetic diversity is in situ conservation wherein native plant species or stock of a biological community is protected and preserved in its natural habitat. According to Hamilton (2003), approaches and methods used to promote in situ conservation and sustainable production of medicinal plants differ little, in principle, from those used for other plants. The types and levels of activities that are possible will vary greatly between projects, depending on the resources of time and money available, as well as the particular interests and competencies of the research team involved.

In a recent study performed by our research team it was suggested that sustainable management could be an option for continuous exploitation if it is compatible with conservation of the ecosystem (Mariot et al., 2002). Sustainable management has, as a basic premise, control over the process of exploitation, seeking to meet social and economic needs but also seeking, more importantly, the maintenance of the forest resource for the continuity of its use and exploitation of raw material (Reis, 1996). In addition, the guarantee of continuity of any exploitative process is related to maintenance of the genetic structure of natural species populations under management (Mariot et al., 2002). Oyama (1993) and Reis et al. (2000) emphasize the fact that effective actions on conservation and management of tropical forests are still limited, and two basic aspects of population biology should be studied in order to provide a basis for these actions: demography and genetics. Since the study of genetic structure and diversity allows knowledge about the organization and distribution of natural populations (Bawa, 1992; Hamrick et al., 1992, Reis et al., 2000), this understanding is indispensable for determining strategies for conservation and exploitation of natural populations in their natural habitats when the objective is the maintenance of diversity and guarantee of sustainability (Oyama, 1993; Nason and Hamrick, 1997; Reis et al., 2000).

\section{Phytotherapeutic standardization}

In contrast to synthetic and pure isolated products from plants, the beneficial effects of phytomedicines typically result from the combinations of secondary metabolites present in plants exerting their therapeutic effects through the additive or synergistic action of several chemical compounds acting at single or multiple target sites associated with a physiological process (Briskin, 2000). In addition, these synergistic or additive pharmacological effects can be beneficial by eliminating the side-effects associated with the predominance of a single compound in the body (Tyler, 1999). Since multiple chemicals could act in an additive or synergistic manner, the active principles responsible for beneficial effects of the phytomedicines, in general, are not so well known. Considering that phytomedicines are standardized herbal preparations containing as active ingredients plant parts or plant materials in crude or processed states, a complete documentation of efficacy, safety and quality control should be required for the registration, use and marketing of herbal products.

Evaluation of the efficacy and safety of phytomedicines depends on each country and their regulatory agencies, but few programmes have been performed to guarantee the efficacy and safety of phytomedicines. In Brazil, as in other countries, evaluation of efficacy and safety of medicinal plants or phytomedicines is restricted to pre-clinical studies, since few clinical trials have been carried out with herbal medicines (Calixto, 2000).

Under Brazilian regulatory guidelines for herbal medicines, our research team has performed pharmacological and toxicological studies to determine pre-clinical efficacy and safety of important herbal products used and commercialized in Brazil as analgesic and/or antiulcerogenic, i.e. Maytenus ilicifolia and their botanical adulterations, Maytenus aquifolium, Sorocea bomplandii and Zollernia ilicifolia (Gonzalez et al., 2001), Wilbrandia ebracteata, a Brazilian pharmacopoeia drug (Gonzalez and Di Stasi, 2002), analgesic, antiulcerogenic and male contraceptive effects of Austroplenckia populnea (Mazaro et al., 2000, 
2002; Seito et al., 2002), and anti-allergic effects of Anchietia salutaris (Di Stasi et al., 1999). In addition, phytochemical and chromatographic profiles were performed to standardize plant extracts and phytomedicines. Several pure compounds were also isolated from these medicinal plants (Di Stasi et al., 1999, 2004; Coelho et al., 2003). The results provided additional economic value to the medicinal plants used and were commercialized by several traditional and rural communities as well as generating very important chemical and pharmacological data for future isolation and chemical elucidation of new products with efficacy and safety. Simultaneously, additional autoecological studies are under development for sustainable strategies determination for each medicinal plant (Mariot et al., 2002). Our experiences have shown that integration among pharmacological and toxicological researches and phytochemistry and agronomic studies for sustainable strategies determination guarantee economic gains and social security for forest people, while new products are generated for use in primary health care and commercialization, promoting development of phytopharmaceutical markets and industries.

\section{Concluding remarks}

The considerations and conclusions inferred from our studies may have wider applications even in other countries rich in tropical forests. Medicinal plants represent a vast repertoire of undocumented and unexploited important economic forest resources that needs investment for appropriate use, in situ conservation, sustainable use, and cultivation harvesting strategies, to meet low-cost and locally available phytomedicines with proven efficacy, safety and quality control. This could be best realized by systematic ethnopharmacological studies, documentation of the therapeutic potential of forest resources and organized cultivation of medicinal plants for raw material production. Further, in order to convert the potential of medicinal plants into economic wealth, it is essential to perform further research to establish development programmes covering pharmacological, toxicological and therapeutical parameters and necessary strategies to produce raw materials for trade and phytomedicine standardization.

It is of the utmost importance that the traditional knowledge base of the forest people is duly safeguarded from capitalist systems. Considering the absence of an internationally agreed methodology for sharing economic benefits from the commercial exploitation of forest products, several problems have occurred including accusations of biopiracy by business and industry, particularly in developing countries that have high biological diversity. It is very important that each country debates this problem and creates regulatory guidelines to guarantee the sharing of benefits for forest people, including protection of traditional knowledge of medicinal plants through patents, development of a database of medicinal plants and determining traditional uses for endemic plant species. It may be pertinent to mention here that the Convention on Biological Diversity (CBD) takes a comprehensive approach for the conservation and sustainable use of biological resources based on sharing benefits between countries which supply and countries which use biological resources, as well as between indigenous or local communities and users in the modern sector. Therefore, countries are expected to operationalize the CBD principles regarding the conservation and use of genetic resources and to define the conditions for access to those resources. It is also necessary that medicinal plant researchers, who use medicinal plants on a small scale, are not prejudiced by legislation implementing the CBD.

\section{References}

Bawa KS (1992) Mating systems, genetic differentiation and speciation in tropical rain forest plants. Biotropica 24: $250-255$.

Briskin DP (2000) Medicinal plants and phytomedicines. Linking plant biochemistry and physiology to human health. Plant Physiology 124: 507-514.

Brito ARMS and Brito AAS (1993) Forty years of Brazilian medicinal plant research. Journal of Ethnopharmacology 39: 53-67.

Bruhn JG and Holmstedt B (1980) Ethnopharmacology: objectives, principles and perspectives. In: Beal JL and Reinhard E (eds) Natural Products as Medicinal Agents. Planta Medica Supplement, 526 pp.

Calixto JB (2000) Efficacy, safety, quality control, marketing and regulatory guidelines for herbal medicines (phytotherapeutic agents). Brazilian Journal of Medical and Biological Research 33: 179-189.

Casamada SM (1968) Farmacognosia con Farmacodinamia. Barcelona: E. Científico-medica.

Coelho RG, Di Stasi LC and Vilegas W (2003) Chemical constituents from the infusion of Zollernia ilicifolia Vog. and comparison with Maytenus species. Zeitschrift für Naturforschung 58: 47-52.

Cronquist A (1988) The Evolution and Classification of Flowering Plants. New York: New York Botanical Garden.

Di Stasi LC, Hiruma CA, Guimarães EM and Santos CM (1994) Medicinal plants populariy used in Brazilian Amazon. Fitoterapia 65: 529-540.

Di Stasi LC, Gomes JC and Vilegas W (1999) Studies on antiallergic constituents in the leaves and stems of Anchietia salutaris var. martiana (Violaceae). Chemical \& Pharmaceutical Bulletin 47: 890-893.

Di Stasi LC, Oliverira GP, Carvathaes MA, Queiroz-Junior M, Tien OS, Kakinami SH and Reis MS (2002) Medicinal plants 
populariy used in Brazilian Amazon Tropical Atlantic Forest. Fitoterapia 73: 69-91.

Di Stasi LC, Camuesco D, Nieto A, Vilegas W, Zarzuelo A and Gálvez J (2004) Intestinal anti-inflammatory activity of paepalantine, an isocoumarin isolated from the capitula of Paepalanthus bromelioides, in the trinitrobenzenesulfonic acid model of rat colitis. Planta Medica 70: 315-320.

Fabricant DS and Farnsworth NR (2001) The value of plants used in traditional medicine for drug discovery. Environmental Health Perspectives 109(Suppl. 1): 69-75.

Farnsworth NR and Morris RW (1976) Higher plants-the sleeping giant of drug development. American Journal of Pharmaceutical Education 148: 46-52.

Farnsworth NR, Akerele O, Bingel AS, Soejarto DD and Guo Z (1989) Las plantas medicinales en la terapeutica. Boletin de la Oficina Sanitana Panamericana 107: 314-327.

Gonzalez FG and Di Stasi LC (2002) Antiulcerogenic and analgesic activities of the leaves of Wilbrandia ebracteata in mice. Phytomedicine 9: 125-134.

Gonzalez FG, Portela TY, Stipp EJ and Di Stasi LC (2001) Antiulcerogenic and analgesic effects of Maytenus aquifolium, Sorocea bomplandii and Zollernia ilicifolia. Journal of Ethnopharmacology 77: 41-47.

Hamilton A (2003) Medicinal plants and conservation: issues and approaches, www.wwf-uk.org/filelibrary/pdf/ medplantsandcons.pdf

Hamrick JL, Godt MJW and Sherman-Broyles SL (1992) Factors influencing levels of genetic diversity in woody plant species. New Forests 6: 95-124.

Laird SA and Pierce AR (2002) Promoting Sustainable and Ethical Botanicals: Strategies to Improve Commercial Raw Material Sourcing. New York: Rainforest Alliance.

Mariot A, Di Stasi LC and Reis MS (2000) Genetic diversity in natural populations of Piper cernuum. Journal of Heredity 93: $365-369$.

Mariot A, Di Stasi LC and Reis MS (2000) Genetic diversity in natural populations of Piper cernuum. Journal of Heredity 93: 365-369

Marit A, Di Stasi LC and Reis M (2000) Genetic diversity in natural populations of. Piper cermuum. Journal of Heredity 93: 365-369.
Mazaro R, Di Stasi LC, and Kempinas WG, (2002) Effects of the hydromethanolic extract of Austroplenckia populnea (Celastraceae) on reproductive parameters of male rats. Contraception 66: 205-209.

Nason JD and Hamrick JL (1997) Reproductive and genetic consequences of forest fragmentation: two case studies of neotropical canopy trees. Journal of Heredity 8: 264-276.

Oyama K (1993) Conservation biology of tropical trees: demographic and genetic considerations. Environment Update 1: 17-32.

Posey DA (1986) Introdução—etnobiologia: teoria e prática. In: Ribeiro BG (ed.) Suma etnológica brasileira-etnobiologia. Petrópolis: Ed. Vozes/Finep.

Prance GT (1991) What is ethnobotany today? Journal of Ethnopharmacology 32: 209-216.

Rates SMK (2001) Plants as source of drugs. Toxicon 39: 603-613.

Reis MS (1996) Manejo sustentado de plantas medicinais em ecossistemas tropicais. In: Di Stasi LC (ed.) Plantas medicinais: arte e ciência-um guia de estudo interdisciplinar. São Paulo: Fundação Editora Unesp, pp. 199-215.

Reis MS, Fantini AC, Nodari RO, Reis A, Guerra MP and Mantovani A (2000) Management and conservation of natural populations in the Atlantic rain forest: a case study of palm heart (Euterpe edulis Martius). Biotropica 32(4B): 894-902.

Savastano MAP and Di Stasi LC (1996) Folclore: conceitos e metodologia. In: Di Stasi LC (ed.) Plantas medicinias: arte e ciência-um guia de estudo interdisciplinar. São Paulo: Fundação Editora Unesp, pp. 37-46.

Seito LN, Mazaro R and Di Stasi LC (2002) Antiulcerogenic and analgesic effects of the Austroplenckia populnea extracts in mice. Phytotherapy Research 16: 193-196.

Tyler VE (1999) Phytomedicincs: back to the future. Journal of Natural Products 62: 1589-1592.

Verpoorte R (2000) Pharmacognosy in the new millennium: leadfinding and biotechnology. Journal of Pharmacy and Pharmacology 52: 253-262.

Young RN (1999) Importance of biodiversity to the modern pharmaceutical industry. Pure and Applied Chemistry 71: $1655-1661$. 